\title{
The Impact of Computer Science on the Development of Oulu ICT during 1985-1990
}

\author{
Henry Oinas-Kukkonen ${ }^{1}$, Jouni Similä ${ }^{2}$, Petri Pulli ${ }^{2}$, Harri Oinas-Kukkonen ${ }^{2}$, \\ and Pentti Kerola ${ }^{2}$ \\ ${ }^{1}$ Faculty of Humanities, History, Centre of Excellence in Research, P.O. Box 1000, \\ FIN-90014 University of Oulu, Finland \\ Henry. Oinas-Kukkonen@oulu.fi \\ ${ }^{2}$ Department of Information Processing Science, P.O. Box 3000, \\ FIN-90014 University of Oulu, Finland \\ Jouni.Simila@oulu.fi, Petri.Pulli@oulu.fi, \\ Harri.Oinas-Kukkonen@oulu.fi, Pentti.Kerola@oulu.fi
}

\begin{abstract}
The region of Oulu has been emphasizing the importance of electronics industry for its business growth since the 1960s. After a pitch-dark recession, the region developed in the 1990s into a new, well-established hub of information and communication technology (ICT) in Finland. The city with its 100,000 inhabitants occupied nearly 10,000 ICT professionals in 1995. This article will contribute to the body of research knowledge through analyzing the role of computer science, in particular information systems and software engineering, for the development of the ICT industry in Oulu in the latter half of the 1980s. This analysis is based on a variety of both primary and secondary sources. This article suggests that the system-theoretical and software-oriented research expertise played a key role for the rapid and successful ICT business development of the Oulu region.
\end{abstract}

Keywords: ICT, Finland, Oulu, history, GSM, telecommunications, mobile, expertise, technology transfer.

\section{Introduction}

Due to a variety of reasons Oulu was in a serious period of recession and unemployment in the 1970s. However, the declining region was able to ride the big wave of electronics innovations. Much of this was a result from the local business networks that enabled an innovative way of working [19]. Moreover, this resulted in a wide interest towards the region of Oulu; for example, instead of seeing a well-known "must" for a Soviet leader, the Lenin Museum in Tampere, the Soviet president Mikhail Gorbachev chose to visit Oulu Technology Park (Oulun teknologiakylä) in his visit to Finland in October 1989 [6, 17].

In the 1980s, the population grew into 103,500 inhabitants. Oulu was the sixth largest city in Finland in 1990. Within the last fifteen years, Oulu has gained approximately 26,000 new inhabitants; however, at the same time for the first time in its history, the number of children under the school-age has dropped below $10 \%$, and, 
simultaneously the number of people over 65 -years-old has risen above $10 \%$. The inhabitants of the city were relatively young and Oulu became the fastest growing region in the country in the 1990s [12].

Students flocked to the university. The University of Oulu had been established as late as in 1958, at the time as the most northern university in the world. The Department of Information Processing Science was established in 1969 [7, 37]. Today, the University of Oulu is a multidisciplinary university, which is typically stated to have created the networks and an innovative basis for the promotion of local production and economy [18]. The yearly student intake of the Department of Information Processing Science gradually increased from the first 10 in 1972 to 25 in 1985 . Companies in the region had close ties with it. For example, Timo Korhonen, a graduate from the department, managed Eurodata's system group. It subcontracted the software development for the embedded cash register system from Dataskill, which also had very strong ties with the department (Juhani Iivari, Seppo Koivumaa and Jouni Similä). During this period, the average number of master's graduates was only 5-10 annually [19]. Despite of its small beginnings, one of the pioneering efforts to give birth to the software industry in the Oulu region was the formation of Blanko conference series, which started in 1973 [18].

The founding of the first software companies took place in the late 1970s - among others, the first software house Dataskill in 1976 and Systepo in 1979. Later, Kari Pankkonen, a graduate from the Department of Information Processing Science, brought forth the software company Modera in 1982. Also computer manufacturers established offices in Oulu, for example Nixdorf in 1979 and HP in 1981 [19]. Yet, it seems that the slow pace of the early 1980s caused the Oulu region to reach out for new ways to support business. Oulun teknologiakylä or Oulu Technology Park ${ }^{1}$ was established in 1982 [10, 57].

In an earlier paper, we discussed the impact of computer science on the development of the ICT field in Oulu region through the first half of the 1980s, and it was found out that the integration of technological, mathematical, and humanistic competence had been successful, a liberal and broadminded intellectualism had been relatively common in the area, and best practices had been actively sought. Moreover, the expertise produced through information systems and software engineering research had played a role in the 'industrial explosion' of the region, in particular via the development of embedded software. Three areas had special significance: 1) a high individual variety of educational knowledge, 2) an awareness of team/project/social cooperation, and 3) systems/software methodological knowledge diffusion and transfer through a value chain originating from the Department of Information Processing Science [18]. This paper maps the earlier results with the findings from the latter part of 1980s, i.e. before the blow of recession in the early 1990s.

The main research challenge in this paper is to understand the impact of information systems (IS) and software engineering (SE) research on the ICT development in Oulu the latter half of the 1980s. The paper focuses on the system-theoretical and software-oriented research expertise behind the rapid and successful business development of the region.

\footnotetext{
${ }^{1}$ An area for high-tech industry following the example of Silicon Valley; known for explosive growth of electronics industry there.
} 
Some authors of this paper are senior scholars at the department; however, they represent different scientific backgrounds and paradigms of the field. They also possess impressive careers in practice, being involved in many of the historical development steps under investigation. Of course, one must carefully scrutinize the primary information provided by using source criticism in line with the scientific research methods of history science. Published literature on high technology in the Oulu region and memoirs of people involved in the events will aid in balancing the view taken to the development. The main newspaper in the region, Kaleva, has been used as a key source for material. This is highly relevant because the magazine participated very actively discussing the development.

In summary, based on a variety of both primary and secondary sources this paper analyses the ICT development in the Oulu region during the latter part of 1980s and the role of computer science in it.

\section{Development of ICT Business Climate from 1985 to 1990}

\subsection{Infrastructure Development - From "Technology Village" towards Technopolis}

The City of Oulu had been somewhat lacking in the activities of forming the technology policy of Oulu during the 1970s and the early 1980s as was noted in our earlier article about the "Oulu phenomenon" [18]. After the polemical public appearances of Antti Piippo in 1979 and the 1980s as executive director of Aspo Electronics, the City of Oulu also actively and massively started to promote the electronics industry and especially the establishment of an electronics park in Oulu, which was finally realized in 1982 [10]. In 1985, however, Technology Park Oulu Ltd (Oulun Teknologiakylä $\mathrm{Oy}^{2}$ ) still functioned in the old dairy near the center of the city notably lacking in space, services, and modern facilities for growing high-tech companies.

In early 1985, the City of Oulu ordered an action plan from the Hansacon consultancy company that came out with two projects. "Technology City of Oulu"3 (Teknologiakaupunki Oulu) would concentrate on the possibilities of development in industry, research, and education. A major initiative was to be the building of the new Technology Park in Linnanmaa near the University of Oulu. "Computer Land of Oulu" (Tietokonemaa Oulu) on the other hand would concentrate on the development of tourism $[4,43]$. The plan was approved by the city administration and both projects were started during the spring of 1985 [8].

${ }^{2}$ Oulun Teknologiakylä translates directly as "Technology Village of Oulu”. Metaphorically this is a very interesting connotation and describes quite well the village type culture and community of the park during the 1980s. However the term technology park is used subsequently following the convention adopted by the organization itself.

3 "Technology City of Oulu" has ever since the early 1980's worked as a very powerful metaphor promoting and marketing the technological know-how from Oulu within the whole country as well as internationally. Later metaphors promoted by the City of Oulu e.g. "Quantum Leap to the Future" or the present "Oulu inspires" have at least so far managed not as well in this task. 
Especially the "Computer Land of Oulu" project, which was later that year renamed as "Tietomaa" ("Data Land"), received much early publicity in the press as may be seen in the references to Kaleva. The Technology Park Oulu, however, came up as a close runner-up and proved to be in the end the required "spice" to transform the city into a real technology center of Finland especially through the decision of the Nokia owned Mobira company, to decentralize its software development in Oulu and in the technology park to be built in Linnanmaa. According to the interview of Heikki Huttunen, director in Mobira, the main reason to start software development activities in Oulu was the availability of qualified personnel provided by the local research and education units. In addition, the decision to start operations in the technology park instead of the Nokia factories in Rusko (a suburb of Oulu) was deliberate. Mobira saw clear possibilities of cooperation with the companies already established in the park and it also considered the proximity of the university a great benefit [13].

\subsection{Growth of Technology Park}

In 1985 when the building of the new technology park in Linnanmaa was started there were 39 companies and about 200 employees registered within the park [44]. We must dismiss one "urban legend" right away. For decades, the rumor in the IT sector in Oulu has been that the Technology Park was built in the form of row houses so that the buildings could be sold to private citizens in case the project did not succeed. Private communication with the architect who designed the first row houses as well as a member of the board of Oulu Technology Park during that time clearly indicated that no such directions were given to the architectural firm and no such discussions were held in the board $[2,34]$. Additionally, it would not have been economically feasible or rational to design the buildings in that manner according to the architect. The rumor is probably due to an interview in 1989 with the managing director Pertti Huuskonen of Oulu Technology Park in which he perhaps jokingly noted that in bad times the buildings could be converted to residential buildings [45]. However, Juhani Saukkonen, one of the employees of Tietomaatio Pasanen in the Technology Park remarked that the standing joke at those times was to refer to the possibility of reallocating the facilities for other purposes of usage, including residential purposes [33].

In the first phase, the technology park was to provide facilities for six companies and a similar size row house was to be started right after the first one was finished. Altogether, in the Linnanmaa area building rights were reserved for 30,000 square meters or for 100-150 companies. The growth of the park proceeded quite rapidly. In August 1985, there were 35 companies and more than 200 employees in the Technology Park [50]. By September 1985, at the start of the building of Linnanmaa area, the number of companies was 39 and the number of employees more than 250; in January 1986, there were 42 companies and about 250 employees [27]. Apparently due to limitations in offered space by April 1986 when Mobira, Outel, Noptel and Prometics occupied the first company row house in Linnanmaa, the number of companies in the park had grown to 44 but the number of employees was still reported as 250 [47]. By May of 1986, the second company row house to be built by November 1986 was already fully reserved and the number of companies was 46 [26]. Plans were changed and instead of building one more company row house a decision was made to construct two company buildings during fall of 1986 and complete the Technology Park 
main building for services needed by companies; additionally, they started discussions regarding raising stock capital [28].

\subsection{Within and Outside "Teknopolis Linnanmaa"}

The growth of the Technology Park was parallel with similar development in companies outside the park in the electronics or other high technology companies. According to an estimate published in October 1986 by Kaleva more than 600 new jobs had altogether been created in the Oulu area compared to 2500 jobs at the time of the establishment of Technology Park [25]. About half of these 600 new jobs may have been created outside Technology Park. As a counterpart, the study reports a similar size loss in jobs in mass industry during the same period. A vigorous restructuring of industry had started.

The growth of the Technology Park continued in 1987. By the inaugural ceremony of the main building in March 1987 there were already 65 companies and about 350 employees listed within Technology Park, about half of them in the Linnanmaa area and half in the city center. In his inaugural ceremony speech the present rector of the University of Oulu Markku Mannerkoski coined the term "Teknopolis Linnanmaa" referring to the whole area comprising the University, Technology Park and Technical Research Centre of Finland (VTT, Valtion teknillinen tutkimuskeskus) [61].

In June 1987 the stock capital of Technology Park was doubled through open issue share from 8 million Finnish marks (FIM) to 16 million with the number of stock owners rising to more than two hundred and plans for listing in the over-the-counter (OTC) outside the stock exchange itself. The "Teknopolis Linnanmaa" term soon gained popularity first in marketing of the area as the original purpose was. In July 1987, the number of companies in Linnanmaa had grown to 50 and in the city center to 30 with altogether about 400 employees [48]. VTT later in August 1987 released its plans to build a sizable building right next to the Technology Park [60] and this truly earned the area the term "Technopolis". Later the term was adopted as a marketing term for the Technology Park using the term "Teknopolis Oulu" and even later in the 1990s, Technopolis Oulu became the official name of the company.

Telenokia announced in November 1987 its plans to construct what would become in 1989 the largest building in the Technology Park. The Telenokia facilities would house in the beginning 100 employees. In November 1987 the Technology Park comprised of 80 companies and 500 employees [49]. Telenokia's plans apparently replaced the earlier published plans by Nokia to build a sizable R\&D center in Oulu; in any case, no such research center outside company production units has ever been built in Oulu [14].

Even though the Finnish Innovation Fund (Sitra, Suomen itsenäisyyden juhlarahasto $)^{4}$ research report in August 1988 on the "Oulu phenomenon" stated that the Technology Park had gone through two strong development phases and was then settling on a development plateau, the number of companies and employees continued to grow [39]. In September, Kaleva reported that the Technology Park had 85 companies and 600 employees. Comparative figures in other Finnish technology parks were: Otaniemi 65 companies and 300 employees, Turku 35 companies and 500 employees, and Tampere 55 companies and 500 employees [40].

${ }^{4}$ Sitra. http://www.sitra.fi/en/ 
Technology Park had also acquired new major high tech companies [36] as well as major enhancements of present companies in the park $[15,16]$. Oulu had begun to interest automatic data processing (adp) companies [20, 23, 41] and electronics industry [5] also generally and some had already made decisions to redistribute software development in Oulu [32]. Internationalization of the Oulu companies was also on the door in a major scale [9]. Major breakthroughs in international markets were published also by companies originating from Oulu [24]. In fact as also the Kaleva article reports, this deal by CCC Software Professionals was already the fourth such project delivered abroad. The labor ministry came to help as well with a special dedicated education program tailored for software houses [58]. In short, the economy was booming. This boom lasted until 1990 when first signs of the coming recession appeared in Kaleva [3].

\subsection{Knowledge Transfer from Research and Education to Practice - Cases of Mobira and CCC}

The economic conditions for growth of ICT companies in Oulu region were very stimulating during 1985-1990. There was plenty of capital and loan money available. The banks readily offered money for loans, so almost anybody could get a loan to buy an apartment or set up a company. We may form a general picture of the development of ICT companies based on Figure 1. The figure shows the number of new ICT companies established yearly from 1968 to 1990 as well as the cumulative number of companies. ${ }^{5}$ In the figure, we see two growth periods: one starting from about the year 1981-1982 and one with an even steeper slope from about 1985-1986. It is noteworthy that the number of companies established during the five years between 1986 and 1990 is more than double the number of companies established during the seventeen years between 1968 and 1985. "Main Threads of ICT Innovation in Oulu in 19601990" provides a more detailed analysis [19].

Knowledge transfer from the Department of Information Processing Science to the practitioners acting in the industry has happened in several ways throughout the years. The major societal impact has of course been the number of students graduating from the department and seeking employment in industry and other organizations. The number of graduates has risen steadily with increased student intakes. During the years 1985 to 1990 , the student intake rose from 25 to 40 and the number of graduates rose from a three-year cumulative average of 7 to about 20 .

\footnotetext{
${ }^{5}$ Sources of the Figure 1: Kaupparekisteri (Trade Register of the National Board of Patents and Registration of Finland, in Finnish). CD-KATKA 1/03 (Helsinki: Patentti- ja rekisterihallitus, 2003); An email message from the Managing Director of Dataskill Oy Seppo Koivumaa, 25.5.2006; Ilkka Heikura, Sähkötekniikan ensimmäiset vuosikymmenet Oulun yliopistossa (Oulu: Avanti Management Oy, 2005); Mika Kulju, Oulun ihmeen tekijät (Helsinki: Ajatus, 2002), Mika Raunio, Luova kaupunki, inhimilliset voimavarat ja kaupunkiseudun kehitys (Tampere: Tampereen yliopisto, 2005); Eino Tunkelo, Oulun teknologiakylä 1980-1988. Miten syntyi Oulu-ilmiö? (Oulu: Suomen Itsenäisyyden Juhlavuoden 1967 rahasto, 1988);"CCC - Finding Solutions", http://www.ccc.fi/1.htm; "Insoft Oy - The visualizer of software development", http://www.insoft.fi/eng/pr2About.htm; "MCon Partners OY", http://www.mconpartners.com/ tiki-index.php?page=Partnerit; "Meet Oulu Hightech - teknologiavierailut", http://www. congressoulu.fi/meetouluhitech/hitechyritykset.html
} 


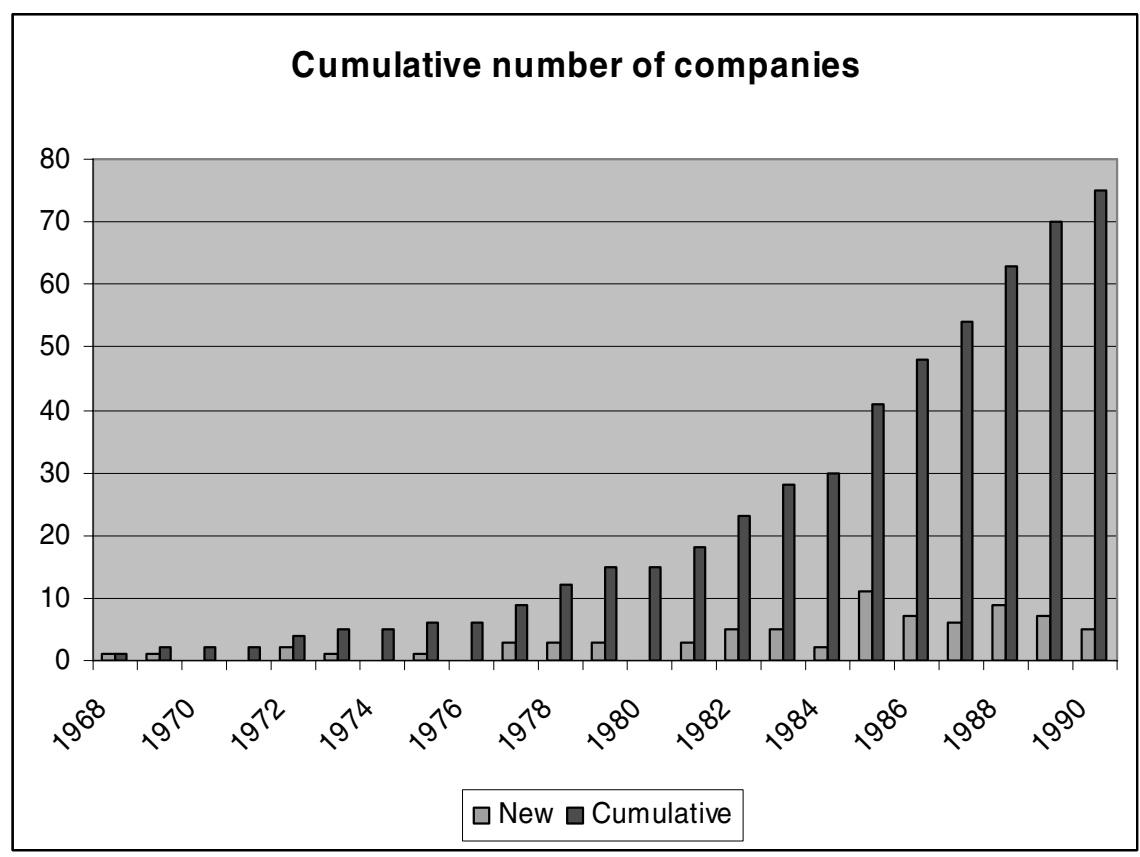

Fig. 1. ICT companies established in Oulu area between 1968 and 1990

Many of the graduates of the department had already started industrial IT companies in the 1980s. The impact of the department's research and education as part of the "Oulu phenomenon" has been analyzed, e.g. in "Development in the Growth Base of the 'Oulu Phenomenon'. The role of systems/software methodologies" [18] and in "Main Threads of ICT Innovation in Oulu in 1960_-1990" [19].

We may trace in a natural way an important part of the societal impact of the activities of the Department of Information Processing Science to the start of student projects already in the 1970s. The student projects - Project 1 and Project 2 - were obligatory courses in the curriculum during the third and fourth year. Both projects were carried out in close cooperation with industry and produced tangible deliverables in a real-like project management situation. Currently, about 40 projects with 3-5 students in each project are carried out yearly with more than 30 industrial clients some projects are reserved for internal departmental and university needs. The student projects have been described in more detail in "How to Teach Project Working Capabilities for Information Technology Students at the University Level" [38]. As one of the results of the student projects the department has had excellent relations with industry now already for more than three decades. These relations have been utilized to hold a steady flow of academy-industry R\&D cooperation projects. It is our intention to investigate later more deeply the impact of the student projects in the knowledge and methodology transfer. 
Business Cooperation:

Project Management Know-how

Project Quality Know-how

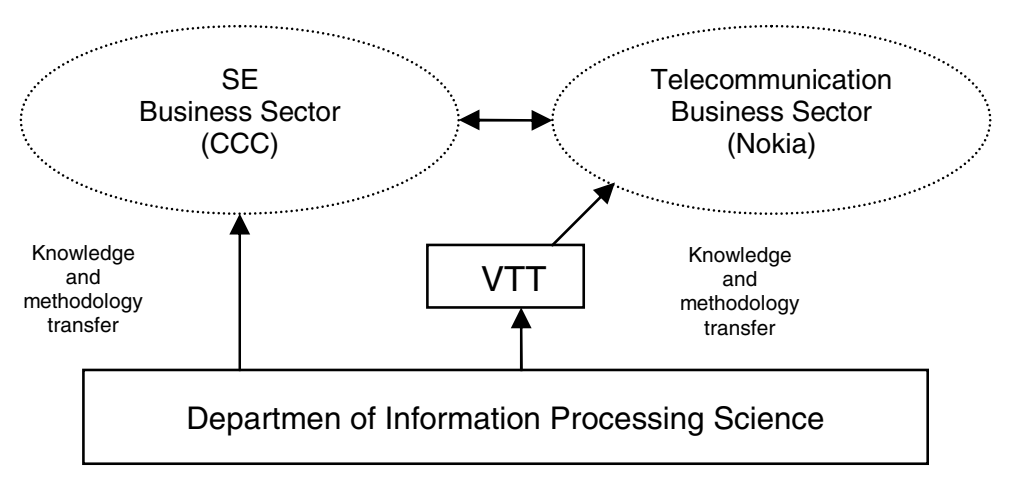

Fig. 2. Knowledge and methodology transfer from Department of Information Processing Science

The cases of CCC and Mobira warrant special attention. Figure 2 shows in a general way the flows of knowledge and methodology transfer to these companies. Timo Korhonen, a graduate of the Department of Information Processing Science, established CCC in 1985. One of the founders of the company, Jouni Similä, is also one of the authors of this paper. The development of the quality system of the company started utilizing a student project from the department in 1985 and led from the company side by Jyri Pyrrö, again a graduate of the department. A series of student projects followed during the coming years. The development of the quality system of the company was later directed by one of the staff and former director of the department, Erkki Koskela, who joined the company in 1988 and became its quality director and later vice executive director. The company eventually became the first software house in Finland to receive the ISO 9001 certificate in 1991.

A favorable development was the growth of Nokia operations in the Oulu region. In the 1980s Nokia had several business divisions in the Oulu region, mainly telecommunications equipment manufacturing (base stations, transmission links, modems, cabling) as well as research and development unit (Nokia Data point of sales terminals) and partial ownership in the Mobira company (later Nokia Mobile Phones). Mobira was finally taken over by Nokia by 1989 . Besides pioneering of Nordic NMT cellular mobile phones, US AMPS and UK TACS mobile phone systems had become commercial successes.

GSM system history has been studied in detail in a Research Institute of the Finnish Economy (ETLA, Elinkeinoelämän Tutkimuslaitos) ${ }^{6}$ report [30] . Basically Nokia had along the pioneering success of analog NMT, AMPS and TACS mobile phone systems become a key player in the development of the second generation digital mobile phone system (GSM) during late 1980s. The development of the GSM

\footnotetext{
${ }^{6}$ ETLA, The Research Institute of the Finnish Economy, http://www.etla.fi/eng/index.php
} 
system was a huge European joint effort that involved hundreds of companies. Nokia was only one of the companies involved. However, through alliances, a focused approach, and commitment it managed to gain a strong position in the GSM development. As an example, in 1988 Nokia entered into an industrial alliance with AEG, Alcatel/SEL and Nokia (ECR consortium) to build, manufacture and sell the GSM base stations. It was a huge task even for Nokia at that time, so a joint effort seemed necessary [30]. However, what was not commonly known at that time, Nokia decided, in parallel to ECR alliance, to develop its own GSM base station. For the Oulu region, Nokia's GSM gamble meant big research and development projects involving several subcontractors.

On the GSM cellular phone development side, Mobira Oulu research and development unit had gained earlier respect for its successfully delivered software development projects. It obtained the required software design expertise from research and academic partners such as VTT and the Department of Information Processing Science. A more detailed report of the knowledge and methodology transfer appears in in 'Development in the Growth Base of the 'Oulu Phenomenon'. The role of systems/software methodologies" [18]. After Nokia took over the Mobira company, the software engineering process knowledge was transferred to several other Nokia units. In Oulu, expertise from the Nokia Data point of sales terminal software was contributing to the mobile phone software expertise, for example operating system and input/output systems and user interface skills and expertise were gained from there. During the period from 1988 to 1990, first prototypes of GSM terminal were built by Nokia (electronics were a size to fill a van) and Nokia Oulu software team was heavily involved. They designed the software architecture of the first GSM phones following RTSA/SD (Real-Time Structured Analysis and Design) method [1].

In the late 1980s, Mobira started to expand its operations in Oulu especially through subcontracting [16]. This did not go unnoticed by CCC but it still took more than a year before people at CCC recognized Mobira as a potential customer. The main attention at CCC during late 1980s was spent on the huge international delivery projects to Soviet Union, which came to a sudden end when Soviet Union collapsed in 1991. The first mention of Mobira in the potential customer lists of CCC was in December 1988 and the first projects began over the next few years. The growth of subcontracting was however quite rapid. In less than five years $\mathrm{CCC}$ became one of the most important subcontractors of Mobira that had changed its name to Nokia Mobile Phones (NMP) by then and in 1995 about one fifth or fourth of CCCs total software development was directed towards NMP. By then, CCC had gained NMP's respect through its superior software project management and quality knowhow [31].

\subsection{Development of Tietomaa and Medipolis}

Tietomaa and Medipolis provide some sidetracks in the development of high tech in Oulu, so it is worth taking a brief look at them. The plans for Tietomaa were grand from the first beginning. The first capital stock was two million Finnish marks (about 330000 euros) and the plan was to increase the capital stock to ten million Finnish marks very rapidly [29]. T total investment need was estimated as 30 million Finnish marks. The City of Oulu decided that it would hold at least $50 \%$ of the capital stock. 
Eventually when the increase in capital stock was announced, it was undermarked so in 1988 the capital was raised to 8.4 million Finnish marks instead of ten million [51].

The idea was also to build the center in Linnanmaa near the University of Oulu; however, this never happened. Instead Tietomaa originally opened its activities in 1986 in an old garage [59] and finally and permanently in 1988 in an old leather factory $^{7}$ both near the center of the city. Descriptive of the high early publicity of the project was that the present managing director, Timo Patja of the Technology Village, gradually withdrew from his position and eventually became the managing director of Tietomaa. High tech companies like Nokia, Datagent, Valmet, FCI Data, Teknoinvest as well as Kunnallistieto and Pohto also joined the center already in 1985 [42].

Eventually, Tietomaa's plan was to build an ICT recreation center or a science center for which the required investment was needed. However, in the beginning Tietomaa concentrated in offering practical ICT courses to professionals working in the industry as well as to laymen interested in the field $[21,54]$. The plans were grand in this as well; the ambitious goal was to raise the $3 \%$ share of the national education markets that the City of Oulu held at that time to a 6-7\% share. Already in 1985 the city government sent the draft training proposal for a request of comment to all relevant parties, including the Department of Information Processing Science [22]. The response of the department was not overenthusiastic; instead the department became active in promoting its own education needs in the public [55]. Tietomaa organized also some ICT conferences from 1985 to 1987 [11, 35, 53, 56]. The education business disappeared from the Kaleva headlines quite rapidly, there is no mention of it in Kaleva from 1988 to 1990. Officially, the education business was finished in 1991 according to the Tietomaa history web pages ${ }^{8}$. There is no mention of conferences as well from 1988 to 1990 in Kaleva so apparently this part of the business disappeared at the same rate.

As a science center, Tietomaa has however been quite successful. In fact Tietomaa was the first science center established in Finland and presently markets Oulu and its know-how nation-wide quite efficiently. The main form of activity presently is the holding of exhibitions which was started already in 1986 [52] and has been continued regularly yearly since 1993 with changing themes.

The road towards Medipolis was started in August 1986 when two biotechnology companies started functioning in the Technology Park [46]. The University of Oulu had already in June 1986 made the decision to establish Oulu Biocenter. Hopes were high for repeating the success of information technology in biotechnology. However even by the present standards, these high hopes were not realized in any meaningful scale and during the late 1980s, progress was minimal.

\section{Conclusion}

The ICT business climate heated up in Oulu in the latter part of 1980s. The Technology Park grew alongside the electronics and other high technology businesses. About a half of the new jobs however were created outside the Technology Park so its effect

\footnotetext{
${ }^{7}$ Tietomaa. History, http://www.tietomaa.fi/eng/tiedekeskus/historia.html

${ }^{8}$ Ibidem.
} 
in the growth of new business was not during this period as prominent as later in the 1990s. Companies such as Mobira and CCC Software Professionals benefited greatly from the accumulated software and systems development competence, in particular related to conceptual modeling and software process modeling. Knowhow on software engineering methodologies and environments transferred well from academia to companies. This was evident in the case of Nokia Mobile Phones and its early operations in Oulu. The ICT growth further accelerated in the 1990s and it had a remarkable impact on the story of Nokia GSM, when the markets really took off around 1995.

\section{Acknowledgement}

We wish to thank Mikko Myllykangas for constructive comments on earlier versions of this paper.

\section{References}

[1] Alanko, J.: Partitioning of layered mobile communication software. Licentiate Thesis, University of Oulu, Department of Electrical Engineering (1994)

[2] Architect Jarmo Similä, employee of Laation Arkkitehtitoimisto in the 1980's, communication on February 10 (2007)

[3] ATK-alan yritykset laman puristuksessa - Tilauskanta supistunut, yrityksiä lopetetaan (Companies in adp field pressed by recession - Volume of orders decreased, companies being closed down), Kaleva, 7.8.1991 p. 15 (1991)

[4] Edellytyksiä kyllä on, kunhan niitä käytetään tehokkaasti. Oulusta voidaan rakentaa Suomen teknologiakeskus (There surely are possibilities once they are utilized efficiently. Oulu can be built into technology center of Finland), Kaleva 30.1.1985, p. 16 (1985)

[5] Elektroniikka Oulun seudulla vauhdissa (Electronics going strong in Oulu area), Kaleva 9.7.1988, p. 16 (1988)

[6] Gorbatshovin yllätysvierailun syyt - Oulun teknologia kiinnostaa Tampereen museota enemmän (Reasons of Gorbatshov's surprise visit - Oulu's technology is more interesting than Tampere's museum), Kaleva 27.10.1989, p. 24 (1989)

[7] Julku, L., Julku, K.: Oulun yliopiston perustamisen historia (History of the Founding of the University of Oulu). Pohjois-Suomen Historiallinen Yhdistys, Rovaniemi, p. 274, 294 (1983)

[8] Kaupunki pääosakkaaksi Oulun tietokonemaahan" (City becomes the main shareholder of the Computer Land in Oulu), Kaleva 10.4.1985, p. 6 (1985)

[9] Kehitysyhtiö näkee vielä paljon tekemätöntä työtä: Oululaiset teknologiayritykset vasta kansainvälistymisen ovella (Development company sees a lot of work to be done: Oulu's technology companies only at the door of internationalization), Kaleva 16.6.1988, p. 19 (1988)

[10] Keskiviikkona perustettu Oulun Teknologiakylä Oy selvä osoitus: Oulun elinkeinopolitiikkaa kehitetään nyt tarmokkaasti (The Technology Park founded on Wednesday gives a clear sign: Oulu's industrial policy is now being developed vigorously), Kaleva, 1.4.1982, p. 18 (1982)

[11] Kotien tietokoneistus uuden askeleen edessä" (Home computerization faces with a new step), Kaleva 20.8.1987, p. 15 (1987) 
[12] Manninen, T.: “Kasvun aika: Oulu 1945 - 1990”, Oulun vuosisadat 1605-2005 ("Period of growth: Oulu 1945 - 1990”, Oulu's centuries 1605 - 2005). Pohjois-Suomen Historiallinen Yhdistys, Rovaniemi, p. 151, 152 (2005)

[13] Mobira hajasijoitti ohjelmistoryhmän Ouluun (Mobira decentralized its software group into Oulu), Kaleva 12.10.1985, p. 20 (1985)

[14] Nokia rakentaa mittavan tutkimuskeskuksen Ouluun (Nokia will build a large research center in Oulu), Kaleva 17.3.1987, p. 22 (1987)

[15] Nokia-Mobira laajentaa: Ouluun matkapuhelimien kokonaiskehittelyä (Nokia-Mobira is expanding: whole development of mobile phones into Oulu), Kaleva 13.8.1988, p. 18 (1988)

[16] Nokia-Mobiran Erkki Veikkolainen: Tieto-taidon myynnillä Oulussa nykyistä enemmän markkinoita (Nokia-Mobira's Erkki Veikkolainen: through selling the know-how more markets than presently in Oulu), Kaleva 26.5.1988, p. 22 (1988)

[17] Oinas-Kukkonen, H.: Moderni ja monipuolinen 'haitekkikaupunki'. Oulun vuosisadat 1605-2005 (Modern and versatile hightech city. Oulu's centuries 1605-2005). PohjoisSuomen Historiallinen Yhdistys, Rovaniemi, pp. 179-181 (2005)

[18] Oinas-Kukkonen, H., Similä, J., Kerola, P., Pulli, P., Saukkonen, S.: Development in the Growth Base of the 'Oulu Phenomenon'. The role of systems/software methodologies. In: Bubenko, J., Impagliazzo, J., Sølvberg, A. (eds.) History of Nordic Computing. IFIP WG9.7 First Working Conference on the History of Nordic Computing (HiNC1), Trondheim, Norway, June 16-18, 2003. IFIP International Federation for Information Processing, vol. 174, pp. 425-447. Springer, New York (2005)

[19] Oinas-Kukkonen, H., Similä, J., Pulli, P.: Main Threads of ICT Innovation in Oulu in 1960-1990. In: Proceedings of Session 90, IEHC 2006, XIV International Economic History Congress, Helsinki, Finland, August 21-25, 2006, vol. 19, p. 2, 18, 19 (2006), http: / /www.helsinki.fi/iehc2006/sessions81_124.html

[20] Ohjelmistotuotantoa suunnataan ulos pääkaupunkiseudulta - Oulussa alan koulutusta laajennetaan ensi vuonna (Software production channeled out from capital city area education in the field will be expanded in Oulu next year), Kaleva 13.10.1988, p. 22 (1988)

[21] Oulu aikoo merkittäväksi tietotekniikan kouluttajaksi (Oulu aims at becoming major information technology educator), Kaleva 9.4.1986, p. 24 (1986)

[22] Oulu selvittää tietotekniikan koulutusta (Oulu investigates information technology education), Kaleva 4.5.1985, p. 5 (1985)

[23] Oulu yhtenä vaihtoehtona - ATK-alan yritykset haluavat maakuntiin (Oulu as an alternative - Companies in ADP field aspire for provinces), Kaleva 8.6.1988, p. 5 (1988)

[24] Oululainen ohjelmistotalo teki miljoonakaupan Neuvostoliittoon (An Oulu-based software house made a million sale into Soviet Union), Kaleva 23.8.1988, p. 16 (1988)

[25] Oululaiset teknologiayritykset luoneet parissa vuodessa 600 uutta työpaikkaa (Technology companies in Oulu have created 600 new jobs in a couple of years), Kaleva 6.10.1986, p. 11 (1986)

[26] Oulun Teknologiakylä kasvaa huimaa vauhtia (Oulu Technology Park is growing with a wild pace), Kaleva 20.5.1986, p. 15 (1986)

[27] Oulun Teknologiakylä paisuu Linnanmaalle (Oulu Technology Park expands into Linnanmaa), Kaleva 25.1.1986, p. 19 (1986)

[28] Oulun Teknologiakylän on pysyttävä virkeänä - Etumatkan varmistaminen noussut haasteeksi (Oulu Technology Park has to stay alert - Securing the head start risen as a challenge), Kaleva 19.6.1986, p. 15 (1986) 
[29] Oulun Tietokonemaa nytkähtää liikkeelle (Computer Land of Oulu is jerked in motion), Kaleva 11.4.1985, p. 15 (1985)

[30] Palmberg, C., Martikainen, O.: Overcoming a technological discontinuity: the case if the Finnish telecom industry and the GSM (Helsinki: Research Institute of the Finnish Economy, 2003), 55 pp. Discussion Papers no. 855 (2003)

[31] Personal archives of Jouni Similä, Technical Director of CCC from 1987 to 1997

[32] Philips hajauttaa Ouluun ohjelmistosuunnitteluaan (Philips decentralizes its software design into Oulu, Kaleva 23.6.1988, p. 19 (1988)

[33] Private communication on April 5 (2007)

[34] Professor Samuli Saukkonen, communication on February 10 (2007)

[35] Publicum -87 tuo Ouluun tietotekniikan uutuudet - Vastauksia käytännön ongelmiin (Publicum -87 brings the new information technology to Oulu - Answers for practical problems), Kaleva 24.7.1987, p. 14 (1987)

[36] Rautaruukille New Technology - yksikkö Oulun Teknologiakylään (A New Technology unit for Rautaruukki into Oulu Technology Park), Kaleva 27.5.1988, p. 16 (1988)

[37] Salo, M.: Pohjoinen Alma mater. Oulun yliopisto osana korkeakoululaitosta ja yhteiskuntaa perustamisvaiheista vuoteen 2000 (Alma Mater of the North. Role of the University of Oulu in higher education and in society). Pohjois-Suomen Historiallinen Yhdistys, Rovaniemi, p. 15, 252 (2000)

[38] Similä, J., Saukkonen, S.: How to Teach Project Working Capabilities for Information Technology Students at the University Level. In: Proceedings of the ISSEU 1997 International Symposium on Software Engineering in Universities, Rovaniemi, Finland, March 6-8 (1997)

[39] Sitran tutkimus etsii uudesta riskirahoitusmallista kiriherkkyyttä menestystarinaan: Ouluilmiön” jatkuvalle voimistumiselle löytyy yhä paikallista ja tehokasta potkuvoimaa (Sitra's research searches spurt responsiveness from a new risk financing model for the success story: Continuous enhancement of the "Oulu phenomenon" is still finding local and efficient sparking power), Kaleva 29.8.1988, p. 11 (1988)

[40] Suomen teknologiakeskukset kurkottavat - Oululaiset asettaneet tavoitteensa korkeimmalle (Finnish technology centers reach out - Oulu has set its goals the highest), Kaleva 7.9.1988, p. 22 (1988)

[41] Suuria ATK-taloja kiinnostaa toimintojen sijoittaminen Ouluun (Large ADP houses interested in relocating their activities in Oulu), Kaleva 27.5.1988, p. 16 (1988)

[42] Teknologiakaupunki Ouluun perustettiin Tietokonemaa (Computer Land has been established in the Technology City of Oulu), Kaleva 20.5.1985, p. 15 (1985)

[43] Teknologiakaupunkikuvaa vahvistetaan (The image of Technology City is strengthened), Kaleva 30.1.1985, p. 10 (1985)

[44] Teknologiakylä aloittaa rakentamisen Linnanmaalla (Technology Park will begin contruction work in Linnanmaa), Kaleva 26.9.1985, p. 18 (1985)

[45] Teknologiakylän anti alkamassa (Issuing of shares of Technology Park about to start), Kaleva 19.4.1989, p. 18 (1989)

[46] Teknologiakylässä aloittaa kaksi biotekniikan yritystä (Two biotech companies about to start operations in the Technology Park), Kaleva 14.8.1986, p. 15 (1986)

[47] Teknologiaprojektien vauhti ei laannu Oulussa (The pace of technology projects not slackening in Oulu), Kaleva 9.4.1986, p. 24 (1986)

[48] Teknopolis Linnanmaa rakentaa tietoverkkoa - Kaksi uutta yritystaloa rakenteilla (Technopolis Linnanmaa builds data network - Two new company buildings under construction), Kaleva 30.7.1987, p. 11 (1987) 
[49] Telenokiasta Teknologiakylän suurin yksikkö - Rakentaminen aloitetaan ensi kesänä (Telenokia to become largest unit in Technology Park - Construction will begin next summer), Kaleva 20.11.1987, p. 17 (1987)

[50] Tietokonemaasta tulee oululaisen osaamisen kaivattu käyntikortti (Computer Land will become the longed-for business card for Oulu's know-how), Kaleva 24.8.1985, p. 15 (1985)

[51] Tietomaa ei ole koskaan valmis (Tietomaa is never finished), Kaleva 11.6.1988, p. 7 (1988)

[52] Tietomaa haastaa elokuun näyttelyllä - Suomalainen tietotekniikan koulutus vielä lähtökuopissaan (Tietomaa challenges with the August exhibition - Finnish information technology education still in the starting pit), Kaleva 17.7.1986, p. 16 (1986)

[53] Tietomaa kokosi atk:n asiantuntijat Ouluun (Tietomaa gathered adp experts in Oulu), Kaleva 7.8.1986, p. 19 (1986)

[54] Tietomaa kouluttaa P-Suomea mikromaailmaan (Tietomaa training the Northern Finland into the microworld), Kaleva 21.4.1986, p. 17 (1986)

[55] Tietotekniikan koulutusmäärät eivät juuri nouse (The numbers of information technology education are not really rising), Kaleva, 14.5.1985, p. 7 (1985)

[56] Tietotekniikan soveltaminen meille sopiva toimintakenttä (Applying information technology a suitable field of action for us), Kaleva 21.8.1987, p. 16 (1987)

[57] Tunkelo, E.: Oulun teknologiakylä 1980-1988. Miten syntyi Oulu-ilmiö? (Oulu Technology Park 1980 - 1988. How was the Oulu phenomenon born?). Suomen Itsenäisyyden Juhlavuoden 1967 rahasto, 1988, Oulu, p. 1 (1988)

[58] Työvoimaministeriö auraa ATK-taloille tietä Ouluun (Ministry of Labour plows way for ADP houses in Oulu), Kaleva 28.6.1988, p. 15 (1988)

[59] Vanhasta autokorjaamosta Oulun Tietomaan lähtöalusta (An old garage becomes the foundation for Oulu's Tietomaa), Kaleva 4.11.1985, p. 5 (1985)

[60] VTT: n talo rakenteilla Oulun Linnanmaalla (VTT's building under construction in Oulu's Linnanmaa), Kaleva 26.8.1987, p. 1 (1987)

[61] VTT: n tuleva pääjohtaja Markku Mannerkoski - Suomi kaipaa huipputekniikkaa tuottavaa omaa teollisuutta (VTT's future general director Markku Mannerkoski - Finland needs its own industry that produces top technology), Kaleva 20.3.1987, p. 16 (1987) 